\title{
The School-Community Partnership: What are the Nature, Type and Challenges of the Partnership on the Development of Education in Lamu East District, Kenya?
}

\author{
1, Abdul Hakim A. Bwana and ${ }^{2,}$ John Aluko Orodho \\ ${ }^{1,}$ Mr. Abdul Hakim A. Bwana is a Doctorate student in the Department of Education Management, Policy and \\ Curriculum Studies, School of Education, Kenyatta University, Kenya \\ ${ }^{1,}$ Prof. John Aluko Orodho is an Associate Professor (specialist in Curriculum Studies, Research and Statistics) \\ in the Department of Educational Management, Policy and Curriculum Studies, school of Education, Kenyatta \\ University., Kenya
}

\begin{abstract}
The gist of this paper was to examine the nature, types and challenges of school-community partnership in the development of education in Lamu East District, Kenya. The study is premised on Getzel (1968) social systems theory which generally deals with open systems. The paper adopted a descriptive survey study design. From a target population of 3,021, a combination of purposive and stratified random sampling was utilized to select a sample of 935 subjects comprising 10 headteachers, 50 teachers, 450 students , 300 parents, 120 community members and 5 Ministry of education officials operating in the study locale. Quantitative and qualitative data was collected using questionnaires and interview guidelines, respectively. The study found that the relationship between teachers and parents was limited to meetings and prize giving days. Also there are no guidelines by the government on school-community partnership. The paper concludes that many parents and community members are reluctant to participate in school activities since the school managers and education officials do not involve parents who have limited academic qualifications in school affairs. Given the overwhelming evidence from credible research findings that schools cooperating with communities around them have a direct impact on overall development, this study strongly recommends direct involvement of communities in almost all aspects of school affairs.(215 words).
\end{abstract}

Key Words: school - community partnership, performance, nature and types of involvement, community, Lamu East District, Kenya.

\section{Background information}

\section{Introduction}

The concept of school-community partnership is enshrined in the Basic Education Act, 2013, No.14 of 2013 enacted through an Act of Parliament to give effect to Article 53 of the Constitution and other enabling provisions responsibility to provide education in Kenya. The Basic Education Act, in part, operationalizes the provision, promotion and regulation of free basic education (Republic of Kenya, 2013). It also stipulates how communities can be brought on board by the establishment of the Board of Management (BoM) whose overriding function is the promotion of the best interest of the institution and ensures institutional development. The other key function of the BoM is to encourage learners, teachers, and non-teaching staff as well as parents and the community including other key stakeholders to render voluntary service to the institution ( Republic of Kenya, 2013). It is through this school-community partnership that would allow reasonable use of the facilities of the institution for community, social and lawful purposes, subject to such reasonable and equitable conditions as it may determine including charging a fee (Republic of Kenya, 2013). The actualization of this schoolcommunity relationship rests with the Board of Management.

The foregoing notwithstanding, one of the most difficult and controversial set activities of institutional managers all over the world is managing communities and forging institutional partnership (Meenyinikor, Timi-Johnson \& Chux-Nyeche, 2014; Orodho, Waweru, Ndichu \& Nthinguri, 2013). In the context of the Basic Education Act 2013, a manager is a person who has been appointed by the Cabinet Secretary in consultation with the proprietor through regulations to coordinate and oversee implementation of education policies and guidelines in non-public basic education institutions and platforms delegated teacher management functions (Republic of Kenya, 2013). In the words of Meenyinikor et.al.(2014), they explain the difficulty experienced in management by stating that it has to do with getting things done through and with people. People, as it is rightly known are human beings and human beings are composed of individuals whose needs and aspirations are dynamic as their nature (Meenyinikor, et.al.2014; Orodho, 2014). Consequently, there are many different that these human beings go about attempting to meet up with their needs and aspirations as 
well as things expected to be available in order to sustainably enjoy them( Orodho, Waweru \& Getange, 2014). Such include the benefits of education and development.

Nonetheless, the notion that school- community partnership and direct involvement in the education of their children enhances achievement is not in doubt as several researches have attested (Otwoma, 2006; Eccle \& Harold, 2009; Epstein, 2008; Darder, 2010; Orodho, 2014). Recognizing that community involvement in education is a major contributor to the success of children in Schools; Darder (2010) avers: Thirty years of research confirms that family involvement is a powerful influence on children achievement in schools. Additionally, Orodho (2014) contends that the involvement of the home- based variables in the educational attainment of a school cannot be underestimated. Otwoma (2006) and Davies (2009) demonstrated that, schoolcommunity partnership enables the school and the community to share the responsibility of running the schools and helping the child to achieve the aim of education without which neither the school nor the community can benefit. The Kenya Education Sector Support Program (KESSP 2005-2010) envisages community involvement in providing support in improving and maintaining existing infrastructure. Kenya adopted Cost Sharing Policy in the education sector in 1988 following recommendations of Report of The Presidential Working Party on Education and Manpower Training for The Next Decade and Beyond, popularly called The Kamunge Report and Sessional Paper No. 6, where parents were to meet the cost of tuition, textbooks and activity fund. In 2003 the National Rainbow Coalition (NARC) Government re-introduced Free Primary Education (FPE) where the parents play the role of providing for facilities, uniforms and other individual essential needs that their children require.

School committees were established by Education Act Cap. 211(1971) Section T (1, 2), and also emphasized by the report of The Commission of Inquiry into Education System of Kenya (Republic of Kenya, 1988 , 1989). This is the only formal partnership between the school and community in Kenya. There is need for the parents and community at large to be involved not only in the provision of funds but also in the control of the expenditure of the same funds they provide. Parents should be involved in decision making process in schools where their children learn. Literature review isolates 6 types of school-community partnership i.e. parenting, communication, volunteering, decision making, and home learning and collaborating with community (Alatorre, 2009; Babour, 2008; Berger, 2007 Comer, 2009).

International Aid agencies and other development partners have put so much effort in funding and supporting programmes such as, text books provision, ICT and infrastructure development to enhance access and retention in education (KIPPRA, 2007). The Basic Education Act 2013 has put in place the Board of Management to bring on board meaningful school community partnership to ensure and assure the provision of proper and adequate physical facilities of institutions (Republic of Kenya, 2013). However, although the government has endeavored to address challenges in the education sector, the situation is not rosy. Issues of access, equity, wastage, teacher shortages, are still a challenge (Republic of Kenya/UNESCO, 2012). Community involvement in education has largely been in the provision of finances and facilities in primary schools, but not much in secondary schools (Getange, Onkeo \& Orodho, 2014). Parents are involved in Annual General Meetings (AGM) and prize giving. There is no national policy about community and school partnerships. Lamu East District within Lamu County is among the least developed districts educationally and performance at national examinations is also dismal among other challenges. It is against this background that the paper wishes to find out the nature and types of community involvement in the development of education and look into issues and challenges in community- partnership in the development of education.

\section{State of Art Review}

The is not a new phenomenon in education literature although modalities of the community and parental involvement in education in terms of the wholesome participation in decision making, home schooling, infrastructure provision, actual teaching, co-curricular activities and overall co-operation has not been well documented(Orodho, Waweru \& Getange,2014, Getange, Onkeo \& Orodho,2014). In the earlier works of Eccle and Harold (2009) observations were rightfully made that, several educationists have tried to explain the meaning of school - community relations in various ways. The underlying consensus is that it refers to sharing of responsibilities, cooperation, working together for the promotion of educational progress. There is need for a two way communication in school community. Information gained through school-community contact will help the teacher to co-ordinate school activities with those of other agencies thus avoiding conflict as well as endorse appropriate supervision to ensure a smooth liaison of the two. Contributing to the same debate, Lawson (2007) argues that where parents have become involved in their own children learning, the children's school performance has invariably improved quiet significantly. The community is the source of learners that is the catchment area. There is every need for teachers and education officials to understand the children's background, environment and cultures for them to appreciate the learners in order to improve other process of teaching and learning. McLaren (2009) in his presentation of the CIES conference in USA identified the following as avenue for partnership: 
a. the community can participate:

b. taking care of buildings and maintaining school plant;

c. planning school policies;

d. employment of staff;

e. monitoring performance;

f. safeguarding school finances;

g. Discipline of students.

It can be pointed out that school - community partnership enhances education achievement and others improve education standards to the benefit of the community. Schools cannot isolate communities and it is this knowledge and conviction that has created interest researchers to find out what exactly is the partnership situation in Lamu East District, and how can it been improved.

Kinyanjui (2009), writing on school administrators maintains that school managers should provide avenues that encourage parental involvement in school affairs. He counsels that the administrators should see the community and partners in education. Katherine (2011) similarly notes that most school heads in Kenya merely involve the community in fund raising activities only. He laments that the community is not involved in spending even the funds they have helped to raise. Karen and Warren (2011) also found that community low level of formal education as another factor that influences co-operation. According to him, most teachers feel that community members would not be able to assist as required because they lack knowledge. The community members themselves also have resigned to the thought that they are not able to provide assistance. What he doesn't clarify however is the kind of assistance. Do parents need to have gone to school for they to be able to supervise cleaning of schools? Cook for the students during national examinations and strategies for the security of the school property. But Kinyanjui, (2009) agrees that it is wrongly assumed that the community support should be only academic like giving lectures on topics given.

There are varied avenues for partnerships where every member of the community has something to offer as assistance, if provided the opportunity. There lacks a model of deliberately involving the community in affairs of the school which this research seeks to find out and recommend possible strategies. In his research Chunga (2006) points out that the fact that co-operation between schools and communities need to be consciously established. It is not a relationship of chance but each group is supposed to understand its role and an enabling environment provided. The partnership is not a one off thing, but rather a cultivated effort that should be reviewed and improved continuously.

In Kenya, parental involvement is realized through the Parents - Teachers Associations, school management committees and old boys girls associations. However apart from the formulation of the PTA and school committees the rest are established at the discretion of individual head teachers and / or education administrators. The PTA in Kenya it started featuring in 1978 when the then President of Kenya, Daniel T. Arap Moi issued a directive that each school should have a Parents Association for secondary schools. However, the PTA concepts within Kenya had started in 1960 when State House Girls School formed their own. Though the PTA is recognized by government, it has never been given a legal mandate like the BOG in school management (Republic of Kenya, 1964).

Besides the Session Paper No. 6 of 1988 on Education and Manpower Training for the next decade and beyond, no other concrete significant move has been made towards this end legalizing PTA. This implies that PTA was established through administrative rules and has no legal status up to now except for those registered under the Societies Act. According to Kiarie (2007) the then Director of Education Kamunge asked schools not to register their PTAs with the Societies Act as PTA was to be included in the Education Act. Membership in PTA is open to all Parents and Teachers of a given school. According to the Education Act 2013, any parent with a student in a given school is eligible for election to become a member of PTA during parents' general meetings every year( Republic of Kenya,2013). Each class is represented by a parent elected by parents or guardians with students in that class. The size of the PTA committee depends on the size and nature of the school e.g. a single stream, double stream, mixed e.t.c. Hence a PTA committee could have 4 teachers and 4 parents for a single stream or 4 teachers and 8 parents for a double stream. Due to affirmative action all PTAs have now to include female representation in their committee by at least a third. The representatives then elect a chairman from among them. The members to be co-opted into the BOG are also elected (Education Act, Cap. 211, 1988, currently the Board of Management (BoM) PTA members are elected annually during the annual general meetings. Members serve for a minimum of one year a maximum of 4 years or within the period of their valid parenting in the schools. A recent study indicates that their activities are mainly limited to approval and financing of development activities in the school (Getange, Onkeo \& Orodho, 2014).

According to Kinyanjui (2008) and Getange et.al.(2014) the functions of PTA include; integrating the schools activities into those of the community within which the school is located, providing the necessary financial support to the school by organizing Harambee for school development projects. This was supported by the 
former President Moi when he stopped the collection of school building and development funds, providing for the necessary equipment and other teaching/learning resources. In line with this they build staff houses. This was supported by the then Education Minister, S. Kalonzo Musyoka as reported in the (Kenya Times of Saturday, February $13^{\text {th }} 1999$ ) when he called on BOG and PTA to plan for improved facilities in their respective schools. By so doing they supplement government efforts to provide facilities, hence cost sharing in schools, ensuring maintenance of discipline amongst students. The former President Moi while addressing teacher-students at Kisii Teachers' College directed that all educational institutions in the country should have parents' days to enable the parents to visit the schools and know the problems facing the students and teachers in instilling discipline. This was supported by KNUT, who indicated that BOG and PTA members should be involved besides teachers.

In summary, the building of a realistic expectation of what the schools can do in a community represents one of the major tasks of any school administrator. Only with such understanding can school procedures make sense to citizens and lead to significant advances in school performances. It is generally said that a school is not an island, but a partnership of the community in which it is located. Members of the community are now or partially involved in the school affairs than ever before. School-community relationship requires particular attention, considering that the 8-4-4 system calls for the participation of parents and the community as a whole in providing funds, facilities and supplies through self-help efforts. As such the head teacher has to be accountable to the community. Despite of the above points it is very important to know how many schools adhere strictly to the school community relations in order to succeed in their educational endeavours. There is a need for the Government of Kenya to come up with policy guidelines on how such relations should be established so that partnership is guaranteed across the board.

\section{Statement of the problem}

Despite the overwhelming evidence indicating that schools co-operating with the communities around them including parents has a direct impact on the success and improved performance in education, there is no unified approach by the government of Kenya on the establishment of such relations. In Kenya, a number of education reports emphasize the need for community-schools partnership in the development of education. However, to date the only participation of parents and community in school affairs is under Parents Teachers Association (PTA) The role of parents has remained to be the provision of finances for infrastructure development, attendance of Annual General Meetings and provision of security and healthcare to their children (Otwoma, 2006; Getange, Onkeo \& Orodho,2014).

Studies world-over have stressed the need for the community and schools to co-operate in a more meaningful manner so as to achieve the goals of education. The community needs to play a role in the curriculum implementation, monitoring of school and out of school activities of teachers and students, communicate more often (Alatore, 2009). The community should be treated as an integral part of the school and their roles seen more as complementary rather than supplementary. School-community partnerships have the potential of developing education in relation to access, retention and quality if well established and nurtures. In Kenya this partnership is left to individual schools and administration to come up with own initiatives and models which works by experimentation. There is no unified approach by the government even when so much has been written about its benefits. It is, therefore, not clear how such partnerships should be established. Therefore this study examined the nature and types of community involvement in school management and the challenges arising in primary schools in Lamu East District, Kenya.

\section{Purpose and objectives of the study}

The purpose of this study is to assess critically and examine the level and nature of school-community partnership and its implication in the development of primary school education in Lamu East District, Kenya. The study focuses on the following two objectives namely:

i) To find out nature and types of community involvement in the management of schools in the development of education, in Lamu East District.

ii) To identify challenges and possible solutions to the challenges of school-community partnerships in the development of education in Lamu East District, Lamu County.

\section{Theoretical Framework}

The study was premised on the social systems theory the theory generally deals with so called open systems. A school is an example of an open system because it constantly interacts with its environment. All organizations can be viewed as open-systems which take input from other systems and through a series of activities transform or convert the significant inputs into outputs (inputs of other systems) to achieve some objectives. 
In terms of this model, the school, for example takes its resources such as people, finance, material and information; transforms and converts these and return them to the environment (society) in the form of changed individuals. In this sense it is impossible for a school to be a closed system. Using this system model the same form of analysis can be applied to all types of organizations. Viewing organizations as systems provides a common point of reference and enables us to take a general approach to the study of organizations, to analyze them and to decide general principles and prescriptions.

The increasing rate of change in major environment factors (technical, economic, social and governmental) has highlighted the need to study the total organization and to adopt a system approach. In order to understand the operations of organizational performance, it is necessary to consider how they achieve an internal and external balance and how they are able to adapt to changes in their environments and the demands placed upon them.

All organizations need clear aims and objectives which will determine the nature of inputs, the series of activities to achieve outputs and the realizations of organizational goals. Feedback about the performance of the system and the effects of its operations on the environment are measured in terms of achieving the aims and objectives. The common elements of management planning, organizing, directing, coordinating and controlling apply in all cases. These essential administrative functions must be carried out in all types of organizations while general principles and prescriptions apply to all organizations, differences in their aims and objectives influence in the input - conversions - output process. The nature of inputs, the conversion process, and the forms of outputs will emphasize characteristic features of a particular organization. These features highlight alternative forms of structure, management methods of operations, and behavior of people employed by or working in different types of organizations. The study of organization as system serves, therefore to indicate both the common features of organizations and also the main distinguishing features between different types of organizations. The systems' view of organizations enables managers to view their own organizations in perspective and to compare it in meaningful terms with other types of organizations.

\section{Research Methodology}

The study employed mixed methods involving descriptive survey research design and multi-case study designs. From an accessible population of 3,021, a combination of purposive and stratified random sampling techniques were used to draw a sample of 935 subjects comprising 10 headteachers, 50 teachers, 450 students, 300 parents , 120 community members and 5 Government agents as summarized in Table 1 .

Table 1: Study Population and Sample selection

\begin{tabular}{|c|c|c|c|}
\hline Respondents & $\begin{array}{l}\text { Target Population } \\
\text { (N) }\end{array}$ & $\begin{array}{l}\text { Sample Population } \\
\text { (n) }\end{array}$ & $\%$ \\
\hline Head Teachers & 19 & 10 & 53 \\
\hline Teachers & 82 & 50 & 61 \\
\hline Students & 1,550 & 450 & 29 \\
\hline Parents & 985 & 300 & 30 \\
\hline Community members & 380 & 120 & 32 \\
\hline Government Agents & 5 & 5. & 100 \\
\hline TOTAL & & 31 & \\
\hline
\end{tabular}

Instruments such as questionnaires and interviews were used in this survey study. Questionnaires were used to collect quantitative data from the teachers and students, interview schedules to solicit data from headteachers and Government officials and focus group discussion to generate qualitative data from parents and members of the community. Quantitative data from questionnaires were analyzed with the aid of statistical package for social sciences (SPSS) computer programme while qualitative data from interviews and focus group discussions were analyzed using thematic approaches involving interview transcriptions and thematic analysis. Quantitative data was generated in terms of descriptive statistics including frequency distributions, picharts and percentages while the qualitative data was presented in narrative and direct quotes.

\section{Nature and types of community involvement}

\section{Findings And Discussion}

The study sought to establish the nature and types of community involvement in the management of schools in the development of education. This includes involvement of parents in school work, means of communication, meetings frequencies, parents visit to schools, teachers' home visits and visits by government officials. 
With regard to the communication channels used to reach parents by headteachers, it was established that the most popularly used method mentioned by 78 percent of the teachers and 70 percent of the headteachers was through verbal communication. It was also evident that the other mode of communication used by 16 percent of headteachers and 20 percent of the teachers was mobile phones to communicate to parents and other members of the community. A negligible proportion comprising of $6 \%$ and $10 \%$ of teachers and headteachers, respectively, used written circulars or letters to communicate.

The focus group discussion with parents on the merits and demerits of these modes of communication revealed that:

In verbal communication the messaged is easily distorted or sometimes never reaches the parent. Children can ignore to relay messages especially if it is about something that they feel the parent should not know. Communication is a critical factor in obtaining a sustainable partnership and in this case it was not sufficient thereby affecting partnership and involvement.

The foregoing citation implies that the schools are not making enough effort to reach the parents and other members of the local community, thereby thwarting any meaningful efforts to create school-community partnerships in the locality.

With respect to frequency of meetings between parents and the school community, it was evident that the meeting frequency was very minimal. This, compounded with limited other avenues between parents and teachers, was one of the shortcomings in the establishment of vibrant school community relations. In countries such as Britain and Nigeria research shows that though meetings are minimal they use other techniques such as monthly report cards, home calls, family get together in order to maintain contact with parents and the society. This level of parents' attendance to meeting is both inadequate and worrying. Berger, (2007) says that building a genuine partnership with parents is a process of continually seeking to understand assumptions and to share meanings. In this case teachers need to find alternative means of encouraging parents and community's involvement.

On whether the head teachers have ever been invited to any community activity, $80 \%$ of the headteachers said they had never been invited. Only $20 \%$ of the headteachers said that they were invited. Those who were invited specified the nature of these invitations which included membership to dispensary committee in the village, fundraising for needy students in secondary schools and also secretary to various social organizations. They also listed other members of the community (non-teachers) whom they work with in schools.

Other community members who were non-parents were invited to school for such occasions like prize giving days, fundraising, Annual General Meeting, resource person to talk to children especially candidates and assistance in providing books and exams. Education officials also visited schools. They included Zonal Education Officers, TAC Tutors, DQASO and DEO. The purposes of their visits were assessment of learning progress, attending AGM and prize giving ceremony, normal meeting attendance, routine inspection, and routine assessment of curriculum delivery and during the election of School Management Committee.

The trend points out to a system deficient of deliberate attempts to foster school-community cooperation outside the traditionally known areas. There is a need for establishing a system that will provide opportunities for interaction and support in education matters so as to improve education standards

Respondents were asked how often teachers, parents and community meet. The responses are indicated in Figure 1. The information carried in Figure 1 indicates the extent to which parents and other members of the community have direct contact with teachers and headteachers.

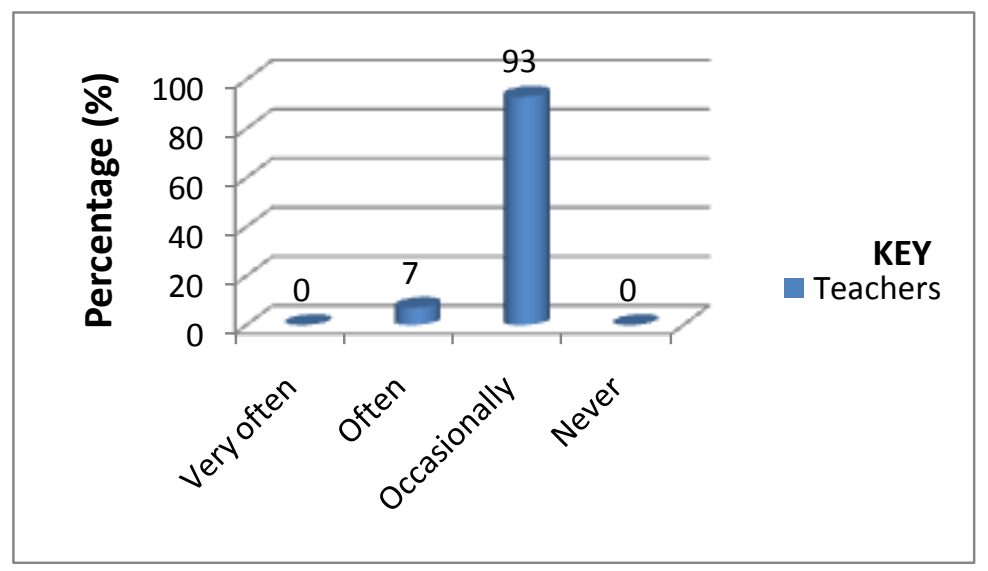

Figure 1: Teachers, Parents and community meetings. 
The results show that over 93 percent of the sampled members of the community visit the schools at most occasionally. This finding is worrying in a country like Kenya where parents should increasingly get involved with the education of their children. In Kenya, the Kenya Education Sector Support Program (KESSP 2005-2010) envisages community involvement in providing support in improving and maintaining existing infrastructure( Republic of Kenya,2005). The study indicated that most of the meetings are done occasionally therefore it is very difficult to implement the formulated policies since contact is limited and by extension; cooperation and support.

In finding out the parents' and community members' involvement in school activities, 37, (73\%) of the respondents indicated that parents' response to invitation was fair while 10, (20\%) said it was poor. Only 3 , (7\%) indicated that their response was good. Other members of the community were invited to school during closing days, prize giving days and graduation days, open days, during games and sports competition, election of School Management Committee.

On establishing whether teachers understood their pupils' background, the study found out that, majority $47(93 \%)$ of the teachers were aware of the background of only a few of their pupils while $3(7 \%)$ were not aware their pupils background at all. This points out to a situation where teachers are not aware of the background of the children they are supposed to mentor. This inhibits the teachers ability to explain why the children behave the way they do. This finding is contrary to what Perrone, (2008) believes teachers could use to establish close working relationships with a family, little by little, we get to know the whole child. Family observations and insights about children inform our teaching and help us better understand children's behavior. Teachers who lack an understanding of their students' culture and home background are most likely unable to establish a meaningful relationship and hence to appreciate strengths and weaknesses which are essential in the formulation of remedial strategies

Parents and other members of the community were asked to indicate the frequency of Education official visits they had made to schools within the community. The responses are presented in figure 2.

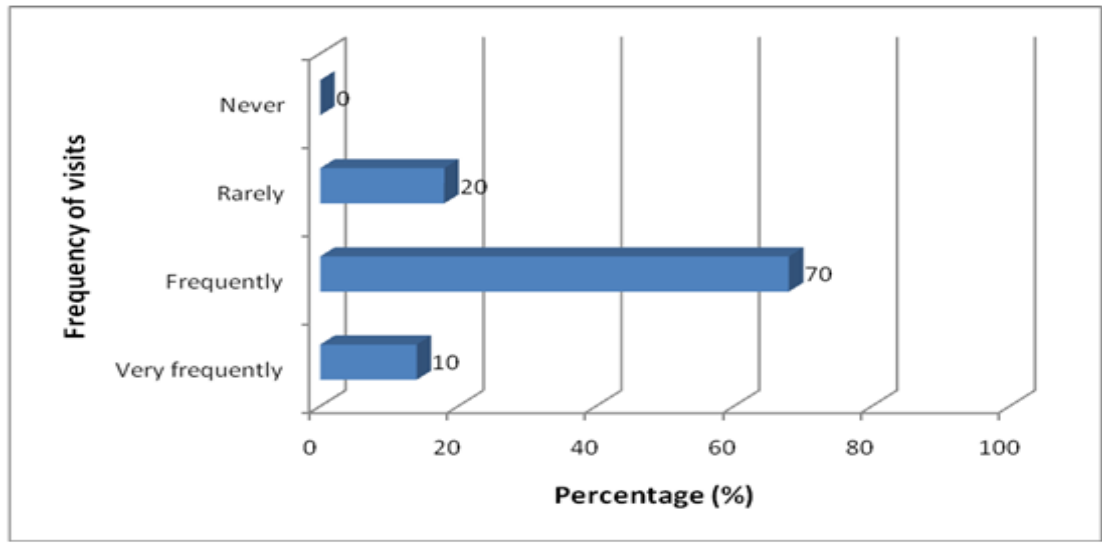

The purposes of the visits were official especially during meetings like Annual General Meeting, election of School Management Committee, inspection of records and assessment of curriculum implementation.

In the Kenyan education set up, education officials by large, Ministry Education is responsible for policy formulation and implementation. Such visits by Ministry officials are essential both as advisory and for monitoring. In this case visits are far apart and thus there is no support given to teachers. Reasons cited for the failure to visit schools frequently, were lack of transport and inadequacy of staff. Also because the area is far from the national office, at any given point two officials were out of the District on officials duties. This takes a whole week in many instances.

Purpose of their visit included payment of levies or pledging on when to pay levies. This agrees with the sentiments of Chadwick (2006) and Laboka, (2007) who contend that one way of improving quality is to provide the funds the schools badly needed in order to run effectively. Parents also attend meetings like AGM, prize giving, closing days or occasionally when called upon for discipline case. The parents played this role very well. They however need to follow up on the usage of the funds and be given opportunities to participate in decision making especially on how these funds are used. Mostly parents cooperated with school administration in giving prizes during prize giving day ceremonies, fundraising, guidance and counseling of pupils, provision of facilities and resources, volunteering skills and labour, provision of stationery, rehabilitation of school classes, volunteer work especially manual work like digging of latrines, payment of levies, helping children at home and sending them to school and taking responsibility over guidance of their 
children. Clifton (2006) envisages 8 eight habits for the heart of educators while building strong school communities through timeless values. In a similar vein, Donbusch and Glasgow (2009) also suggest types of school-community partnership i.e. parenting, communication, volunteering, decision making, and home learning and collaborating with community.

\section{Challenges facing school-community partnerships in the development of education}

The study looked into challenges facing the establishment of school - community partnership in the development of education. These were given by head teachers, teachers, Parents and education officials through focus group discussion. The dominant voices were as follows:

Challenges facing teachers in trying to involve the community in school affairs are several. They include teachers isolating themselves and not receptive to ideas from parents. Parents and community members don't attend meetings and are reluctant to participate in school activities and others are not interested in participating in school affairs. Many parents believe school work is for teachers. Opportunities for co-operation are also limited.

With regards to hindrances of parents to participate in the monitoring of education for their children, the following sentiments emerged from focus group discussion:

....lack of knowledge, lack interest in school work or are very busy, have not realized their roles, View teachers as masters and feel that it's their work....

Greatest challenges faced by head teachers in establishing partnership with parents and other members of the community include the following:

......the attitude that school work is for teachers, parents are absent in the villages, there are no people initiating this, It has never featured in their discussions....

Challenges given by Government officials that school-community relations face include:

...lack of uniform approach on issues, lack of official policy, parents view school affairs as exclusively belonging to teachers and education officials, bureaucracy in school management locks out parents' involvement and finally, opportunities for partnership are not identified...

Pupils were asked on what they wish their parents did in their school life. The following was gathered from their responses:

they needed helped in school work, talking more with parents about school, provided reading materials, assisted in homework, play together, come to school regularly to see the teachers, assist in providing rooms and tables for studies.

Head teachers wished education officials did more in establishing school-community by :

..Initiating dialogue between parents and teachers, visiting the schools more often, giving assessment reports back to the teachers as feedback, conducting sensitization workshops between parents and teachers, establishing avenues to involve parents in school activities and supporting the schools posting adequate teachers....

In the views of the students, ways in which parents and other community members could be of help in relation to school - community partnership were many but included the provision of feedback on the child's needs and aspirations so that remedy could be sought, motivating students and teachers, giving moral support to children, assisting in modeling children's behavior, and help in giving suggestions on how programs can be improved.

Suggestions by teachers towards fostering school-community relations included:

holding regular meetings, involving parents not only in fundraising and discipline issues but also in school activities regularly such as in games and sports days, teachers and parents hold regular meeting and those parents who failed to attend should explain. Skilled parents should be allowed to participate in volunteer work like painting.

On their part, teachers and school managers thought parents and other members of the community could assist in the management of the schools in the following ways:

...enhancing access and retention, provision of infrastructure, advisory and support in finances and other resources, demanding to know the affairs of the school, finance, games and talking to students...

Apart from the traditionally established partnership modes, parents and community members can be involved in the delivery of curriculum. Resource persons from amongst the parents and local leaders e.g. religious or otherwise can be utilized to teach certain identified components of the curriculum.

It was further evident that teachers and school managers were positive on the role of all members of the community. They observed that even illiterate or semi-illiterate members could use their skills, competencies and experience to participate in areas like football coaching, agricultural skills, and molding the moral character of teachers and students etc.

On their part, the education officials were unanimous in accepting that there was a deficiency in national policy to guide establishment and maintenance of collaboration and partnership between schools and communities around them. In many instances, they lamented that members of the community were considered as aliens to the school to the extent that they could not even access playing fields and school halls within their 
reach. This is contrary to the expected interrelationship by the Basic Education Act 2013 which allows reasonable use of the facilities of the institution for community, social, and lawful purposes, subject to such reasonable and equitable conditions as it may determine including charging a fee( Republic of Kenya, 2013).

In a similar vein, Lawson (2007) has convincingly argued that where parents have become involved in their own children learning, the children's school performance has invariably improved quiet significantly. The community is the source of learners that is the catchment area. There is every need for teachers and education officials to understand the children's background, environment and cultures for them to appreciate the learners in order to improve other process of teaching and learning. In fact, these sentiments are in line with the Basic education Act which advocates for establishing a conducive learning environment that facilitates students' academic and overall development through cooperating with the community through well established parents' teacher associations (Republic of Kenya, 2013).

\section{Conclusion And Recommendations}

The thrust of this study was to examine the current school-community partnership in the development of education in primary schools in Lamu East district, Lamu County, Kenya. It was evident that majority of sampled respondents were almost unanimous that there was need for the establishment of a strong schoolcommunity partnership in the study locale. They specifically pinpointed the importance of them keenly cooperating with school teachers for the benefit of their children but they were unaware of how to do it. They felt that school management did not involve them probably because of their low level of formal schooling. The paper concludes that many parents and community members are reluctant to participate in school activities since the school managers and education officials do not involve parents who have limited academic qualifications in school affairs. There is therefore, an urgent need for the Government of Kenya to come up with a policy and guidelines on how such partnerships can be established. The areas that received prominence regarding challenges and opportunities regarding school-community partnership in the development of education in the locale and which require urgent attention were:

First, most teachers and school managers isolated themselves from parents and other members of the community. It was felt that they were not receptive to ideas from parents and other members of the community. As a result, this weakened the envisaged school- community partnership.

Secondly, parents and community members didn't attend meetings when called and the few who attended were reluctant to participate in school activities while others were simply not interested in participating in school affairs. Many parents believed school work is for teachers and school managers.

Thirdly, specific strategies to counter these challenges emerged during the study. These included: the need to hold regular meetings, meaningful involvement of parents not only in fundraising and discipline issues but also in regularly extracurricular activities such as games and sports during ball game season, holding regular meetings between parents, students, teachers and members of the management team, and sensitization of parents who persistently fail to turn up for meeting regarding the importance of the school-community partnership in the development of education by following them to their homes. In addition, skilled parents and other members of the community should be encouraged and given an opportunity to participate in volunteer work such as coaching of game balls and sports, guidance and counseling, preaching, painting and involvement in income generating enterprises.

Finally, the overall conclusion was that the lack of meaningful involvement of the school managers in forging effective school-community partnership was lack of leadership skills. This is because the way community members had been involved in school affairs was wanting. Despite the fact that the principals had the required academic qualifications with long teaching experience, their public interpersonal relationship skills did not make a distinction between the students and students, students and teachers, teachers and teachers, teachers and members of the school management as well as school management and community, hence creating a possibility of either a love-hate relationship or lack of bonding between the different groups. Some of the worst case scenarios included incidences where the headteacher in collaboration with the Board of Management do not motivate their staff to achieve better results or where the school managers fail to give leadership in time of crisis. This was contrary to the expectation of the Basic Education Act, 2013 which categorically states that principals through school management Boards should encourage the teachers, students, non-teaching staff and the community as well as other stakeholders to render voluntary service to the school ( Republic of Kenya, 2013), hence harnessing school-community concerted efforts geared towards overall development of the schools.

On the basis of the findings of this research study and discussions based on the reviewed literature, it is recommended that:

1. Schools should open up communication channels with the community in their school through elaborate school strategic plans. The members of the local community, especially parents, should be sensitized regarding the critical roles they can play in various school development activities. This should be followed with the 
identification of the priority areas where the resource persons identified from the local community with the requisite knowledge and skills could be involved. Given the overwhelming evidence from credible research findings that schools cooperating with communities around them have a direct impact on overall development, this study strongly recommends direct involvement of communities in almost all aspects of school affairs

2. Guidelines should be developed by the Ministry of Education to assist school principals in collaboration with the Management Boards to establish partnership opportunities. Thus, it is recommended that the schoolcommunity partnership through the Board of Management should promote the best interests of the school and ensure and assure institutional development in all aspects not only in term of physical and human resource development but also academic and non-academic excellence.

3. The Ministry of Education in consultation with the Teachers Service Commission (TSC) should insist on inculcation of leadership knowledge and skills for all school managers through an elaborate professional development plan, especially on appointment of principals and members of the management Board. The TSC should move away from appointing principals based only on academic papers but and adopt a competency in leadership skills approach as the guiding principle in appointment of headteachers and their future promotions.

\section{References}

[1]. Alatorre, S., (2009). Redefining School and Community Relations: Teachers Perceptions of Parents as Participants and Stakeholders in Education. London. Penguin Publishers.

[2]. Barbour, C., (2008). Families, School and Communities Building Partnerships for Educating Children ( $3^{\text {rd }}$ Edition). Cologne. West View Publishers.

[3]. Berger, E., (2007). Parent as Partners in Education: The School and Home Working together. New York. MacMillan Publishing Press.

[4]. Chadwick, K. G., (2006). Improving Schools through Community Engagements: A Practical Guide for Educators in Developing Countries. London. Donnell/Crawfordsville Publishers.

[5]. Chunga, L. N., (2006). The Basics of Administration in Relation to Schools and the Society at Large. New York. Penguine Publishers.

[6]. Clifton, T., (2006). Eight Habits of the Heart for Educators: Building Strong School Communities Through Timeless Values. New York. Bell Howell Publishers.

[7]. Comer, J. P., (2009). School Reaching Out: Family School and Community Partnerships for Students Success of Children Education and Urban Society. New York. Thomas Hoffer Basic Books Publishers.

[8]. Darder, J. J., (2010). What is Happening in Primary Schools and the Community? New York. Sterling Publishers. Limited.

[9]. Davies, D., (2009). Home-School Relationships as they affect the Academic Success of Children in Developing Countries. Philadelphia. Delta Kappan Publishers.

[10]. Donbusch, L. and Glasgow, S., (2009). School and Home in Education: A Review of Development in School and Home relationships. New York. Penguine Publishing Press.

[11]. Eccle L. and K., Harrold (2009). The Impact of Parental Involvement, Parental Support Support and Family on Pupil Achievement and Adjustment: London. John Wiley and Sons Publishers.

[12]. Epstein, J. (2008). Perspective and Previews on Research and Policy for School, Family and Community Partnerships. New Jersey. Lawrence Erlbaum Publishers Associates.

[13]. Gardner, K., (2007). Improving Schools through Community Engagement: A Practical Guide Guideline for Educators. London. Penguin Publishers.

[14]. Getange.K.N.,Onkeo.M.J.,Orodho.A.J.(2014).Alternative sources of funding for free day secondary education in public schools in Kisii Central District, Kisii County, Kenya. International Organization of Scientific Research (IOSR); Journal of Dental and Medical Sciences (IOSR-JDMS). Vol.13, Issue 4, Ver.VI.(April.2014),pp14-23.www.iosrjournals.org .

[15]. Karen, L., and Warren, M., (2011). A Match on Dry Grass: Community organizing as a Catalyst for School Reform. London. Oxford University Press.

[16]. Katharine, B., (2010). Impact of Welfare on Children, Parents, Teachers and Schools: Inter-professional Challenges and Opportunities. London. Worburn Publishers Limited.

[17]. Kiarie, E. P. (2007). Factors that Affect School Community Relationships. A Case of Thika District Secondary Schools. Nairobi. Kenyatta University Unpublished Project.

[18]. Kinyanjui, M.C., (2009). Reflections on Education in East African Countries. Nairobi. Oxford University Press.

[19]. KIPPRA (2007). Achieving Primary School Education in Kenya. The Educational relationships between School and community. GOK Press.

[20]. Laboka. N. (2007). Widening Access to Education as a Social Justice to the Stakeholders. London: SAGE Publications.

[21]. Lareau, J.(2006). Empowering Teachers and Parents in Schools in Sub-Saharan Africa Countries. New York. Delta Kappan Publishers.

[22]. Lawson, A. H., (2007). Two Frameworks for Analyzing Relationships among School Communities, Teacher Education and Interprofessional Education and Training. Paris. University of Notre-Dame Press.

[23]. Lewin, T. (2006). An Assessment of Community Schools and Students in their relationships in Education in Uganda. Kampala, Lubaga Publishers Limited.

[24]. McLaren, S., (2009). Education and Community Relationships: A Step towards Educational Globalization. London. Oxford University Press.

[25]. Miller, M.D., (2010). High School Parent Involvement: Relationships with Achievement, SES and Gender. Journal of Research and Development in Education, Volume 16.

[26]. Muigai, C. (2008). Schools Practices as Parental Involvement (DE) Motivators: A Case of Public Secondary Schools in Mombasa District, Nairobi. University of Nairobi.

[27]. Meenyinikor, J.N.D, Timi-Johnson, T.C.,\& Chux-Nyeche. G ,C.(2014).Managing Nigerian Tertiary institutions : A panacea for national development. International Journal of Education, Learning and Development. Vol. 2. No.1. pp17-33, March 2014.www.ea.joornals.org . 
[28]. Orodho, A. J., (2012). Elements of Education and Social Science Research Methods: Department of Educational Management, Policy and Curriculum Studies. Kenzia Publishers. Maseno. Kenya.

[29]. Orodho, A.J.(2014).Attainment of education for all (EFA) by 2015: From rhetoric chimera to practice in Kenya. International Journal of Current Research. Vol. 6. Issue 01, pp4666-4674. January 2014. www.journalcra.com .

[30]. Orodho, J.A., Waweru, P.N., Ndichu, M., \& Nthinguri, R .(2013). Basic education in Kenya: Focus on strategies applied to cope with school-based challenges inhibiting effective implementation of curriculum. International Journal of Education and Research (IJER).www.ijern.com .

[31]. Orodho,A.J, Waweru, P.N. \& Getange, K,N.(2014).Progress towards attainment of education for all (EFA) among nomadic pastoralists : How do we dismantle the gender differential jinx in Mandera County, Kenya?.International Organization of Scientific Research (IOSR), Journal of Humanities and Social Sciences (IOSR-JHSS). www.iosrjournals.org .

[32]. Otwoma, A. D., (2006). Home Environment and the School in relation to Education. London. University of London Press.

[33]. Perrone, F., (2008). Family Involvement in Childrens' Education: Success Local Approaches office of Educational Research and Improvement. New York, US Department of Education.

[34]. Pogorin, B., (2007). Towards Theory of Family and School Connection: Teachers Practices and Parents Involvement. New York. Praeger Publishers Company.

[35]. Republic of Kenya .(1964). The Ominde Education Report, Nairobi Government Press Ltd.

[36]. Republic of Kenya. (2005a).) Sessional Paper No. 1 on Policy Reforms for Education, Training and Research: Meeting the Challenges of Education Training and Research in the $21^{\text {st }}$ Century. Ministry of Education, Science and Technology (MOEST Nairobi: MOEST.

[37]. Republic of Kenya(2005b). Kenya Education Sector Support Programme 2005 - 2010: Delivering Quality Education and Training to All Kenyans. Nairobi: MOEST.

[38]. Republic of Kenya.(2012a).Sessional Paper No.14 of 2012 on realigning education and training to the Constitution of Kenya 2010 and Vision 2030 and beyond. Ministry of Education Science and Technology. Nairobi. Kenya.

[39]. Republic of Kenya.(2012b).A Policy Framework for re-aligning education to the Constitution 2010 and Vision 2030 and beyond.

[40]. Republic of Kenya.(2013). The Basic Education Act, 2013 No 14 of 203.The Government Press, Nairobi.

[41]. Republic of Kenya/UNICEF( 2012).Education for All (EFA) End of Decade Assessment (2001-2010). Ministry Of Education and INICEF. Nairobi.

[42]. Tekcle Marian, S., (2008). The Main Boundaries between the School, Family and the Community: An Educational Perspective. London. Corwin Press.

[43]. Wright, K., and Dolores, S., (2009): Building School and community Partnerships Through Parent Involvement (2 ${ }^{\text {nd }}$ Edition). London, Prentice Hall publishers.

[44]. Zuniga, C., (2011). Redefining School of Parent as Participants and Stakeholders in Education. Baltimore. CBS Publishers. 